\title{
ANALISIS STRUKTURAL CERITA CILINAYE: UPAYA MENGUNGKAP KEARIFAN LOKAL MASYARAKAT SASAK
}

\author{
STRUCTURAL ANALYSIS OF CILINAYE TALE: A STUDY OF REVEALING \\ LOCAL WISDOM OF SASAK
}

\author{
Muhammad Shubhi \\ Kantor Bahasa Provinsi Nusa Tenggara Barat \\ shubhi.muhammad@gmail.com \\ Tanggal naskah masuk: 1 Oktober 2012 \\ Tanggal revisi terakhir: 19 November 2012
}

\begin{abstract}
This writing is aimed at analyzing the structure of Cilinaye tale to reveal its local wisdom. In order to reach the goal, this writing uses Levi-Strauss structuralism theory that views mite (tale) has similarity to its medium of transfer, language, and has structure. It is found that Cilinaya tale has list structure in which each part explains by others. By understanding the structure of Cilinaya tale, it would help to reveal its local wisdom. It is shown from some behaviors and deeds told by the tale. Visiting grave, prayer, and vow are three related things. There is a strong motivation to get the expectation in vow. Besides, there is a cultural ceremony followed Peresean which is the local wisdom owned by Sasak community reflecting thank God.
\end{abstract}

Key words: tale, structuralism, local wisdom

\begin{abstract}
Abstrak
Tulisan ini bertujuan untuk menganalisis struktur cerita Cilinaye guna mengungkap kearifan lokal apa saja yang terkandung di dalamnya. Untuk sampai kepada tujuan tersebut, tulisan ini didasarkan pada teori Strukturalisme Levi-Strauss yang melihat bahwa mitos (cerita) memiliki kemiripan dengan bahasa yang merupakan media penyampaian pesan dan memiliki struktur. Hasil analisis menemukan bahwa cerita Cilinaye memiliki struktur yang saling kait-mengait, bagian yang satu menjelaskan bagian yang lain. Dengan memahami struktur cerita Cilinaye tersebut, dapat mempermudah mengungkap kearifan lokal yang ada di dalamnya. Hal itu terlihat dari beberapa sikap dan perbuatan yang ditunjukkan dalam cerita. Ziarah makam, doa, dan nazar merupakan tiga hal yang erat kaitannya. Dalam nazar terdapat juga sebuah motivasi yang kuat untuk meraih apa yangmenjadi harapan. Selain itu, adanya perayaan disertai dengan presean juga merupakan kearifan lokal yang dimiliki oleh masyarakat Sasak sebagai perwujudan rasa syukur.
\end{abstract}

Kata kunci: cerita rakyat, strukturalisme, kearifan lokal

\section{Pendahuluan}

Kearifan lokal menjadi salah satu topik yang sering disebut belakangan ini terkait dengan sastra. ${ }^{1}$ Lebih lanjut Ahimsa-Putra mengatakan bahwa semangat meneliti kearifan lokal sejalan dengan semangat masyarakat untuk memperhatikan dan mengungkap budaya-budaya suku bangsa. Semangat reformasi ternyata memberi dampak positif terhadap perhatian masyarakat akan kekayaan budaya etnik yang selama ini diserahkan urusannya kepada pemerintah. Semangat tersebut 
tentu menjadi sesuatu yang positifjuga bagi ketahanan sastra daerah. Kita pasti tidak ingin melihat apa yang selama ini kita miliki dan mengakar kuat dalam kehidupan sehari-hari lebih mendapat perhatian dari pihak yang bukan bangsa sendiri atau bahkan menjadi milik negara lain. Hal ini bukan berarti juga bahwa semua yang kita miliki tersebut harus kita simpan aman begitu saja.

Salah satu dari sastra daerah tersebut adalah sastra Sasak. Sastra Sasak memiliki banyak bentuk dan jenis. Dari sekian banyak bentuk dan jenis tersebut, yang akan dipilih adalah jenis cerita rakyat Sasak dan dari sekian banyak cerita rakyat Sasak yang ada, tulisan ini akan difokuskan pada cerita rakyat yang berjudul Cilinaye. Judul Cilinaye berdasarkan pada keterangan yang didapatkan dari seorang informan yang mengatakan bahwa judul di dalam naskah adalah Cilinaye. Hal ini dipertegas karena dalam masyarakat, cerita yang sama disebut sebagai cerita yang berbedabeda, ada yang menyebutnya sebagai cerita Datu Keling Datu Dehe, ada juga yang menyebutnya cerita Amaq Bangkol Inaq Bangkol.

Kajian terhadap cerita Cilinaye ini telah banyak dilakukan oleh para peneliti sebelumnya. Sepanjang pengetahuan dan informasi yang didapatkan penulis, penelitianpenelitian tersebut di antaranya adalah penelitian yang berjudul Analisis Alur Geguritan Cilinaya: Laporan Penelitianyang dilakukan oleh Nuarca,
Geguritan Cilinaya: Sebuah

Pendekatan Strukturalisme yang dilakukan oleh Saidi dkk, Kajian Nilai Geguritan Cilinaya: Laporan Penelitian oleh Cok Istri Agung Mulyawati R. dan terakhirpenelitian yang berjudul Cerita rakyat Lombok Dongeng Cupak Gerantang, Sandubaya dan Lala Seruni, dan Cilinaya oleh Khaeriati. ${ }^{2}$

Dalam kaitannya dengan penelitian ini, dari keempat penelitian yang disebutkan di atas, terdapat tiga penelitian pertama yang memiliki objek penelitian yang berbeda. Walaupun sekilas memiliki objek yang sama yakni Cilinaye, ketiga penelitian tersebut sebenarnya memiliki objek yang berbeda. Ketiga penelitian tersebut meneliti Cilinaya yang hidup dan berkembang dalam tradisi kesastraan Bali. Sedangkan penelitian ini meneliti Cilinaya yang hidup dan berkembang dalam tradisi kesastraan masyarakat Sasak, Lombok.

Objek yang sama diteliti dalam penelitian yang keempat, yakni samasama merupakan cerita Cilinaya yang hidup dan berkembang pada masyarakat Sasak. Akan tetapi penelitian tersebut berbeda dengan penelitian yang dilakukan oleh penulis. Perbedaan terletak pada fokus penelititan. Penelitian ini fokus pada analisis struktural cerita Cilinaye untuk dapat mengungkap kearifan lokal yang terdapat di dalamnya. Cerita Cilinaye ini juga pernah diteliti bersama cerita Sasak lainnya oleh Safaruddin, dkk. ${ }^{3}$ 
dalam penelitian yang berjudul Orientasi Nilai Budaya Etnis Sasak yang Tercermin dalam Cerita Rakyatnya dengan menggunakan metode struktural-semiotik dan rumusan permasalahan yang berbeda. Dapat terlihat bahwa penelitian tersebut merupakan penelitian yang berbeda dengan penelitian ini dari segi teori yang digunakan dan fokus masalah. Berbeda permasalahan dan teori yang digunakan, akan berdampak pada hasil yang didapatkan. Dengan demikian penelitian ini tetap layak untuk dilakukan.

Penelitian ini dilakukan di Pulau Lombok sebagai tempat persebaran cerita Cilinaye. Data penelitian ini berupa cerita Cilinaye. Cerita didapatkan dari hasil wawancara dengan seorang informan. Informan tersebut dipilih langsung berdasarkan pertimbangan bahwa informan tersebut merupakan pencerita dan sekaligus pemilik naskah. Informan diminta untuk menceritakan cerita Cilinaye. Hasil dari rekam inilah dijadikan bahan untuk melakukan analisis.

Tulisan ini ingin menjawab dua permasalahan, yakni bagaimana struktur cerita Cilinaye dan bagaimana kearifan lokal masyarakat Sasak yang terdapat dalam cerita Cilinaye. Tujuan yang ingin dicapai dalam penelitian ini dapat dikatagorikan menjadi dua tujuan, yakni tujuan teoritis dan tujuan praktis. Tujuan teoritis penelitian ini adalah menerapkan teori strukturalisme Levi-Strauss dalam cerita Cilinaye guna menambah khazanah kajian cerita rakyat Sasak. Secara praktis penelitian ini bertujuan untuk memudahkan pembaca memahami secara mendalam struktur cerita Cilinaye. Dengan demikian, para pembaca dengan mudah menemukan kearifan lokal masyarakat Sasak yang terdapat dalam cerita tersebut.

\subsection{Kerangka Konseptual}

Penelitian ini berlandaskan pada konsep strukturalisme yang dikemukakan oleh Levi-Strauss. Konsep strukturalisme merupakan salah satu konsep dalam model pendekatan objektif. Pendekatan ini memberi perhatian penuh pada karya sastra sebagai struktur yang otonom dengan koherensi intrinsik. ${ }^{4}$ LeviStrauss menganalisis ratusan mitos yang tersebar di berbagai tempat dengan menggunakan model-model dari linguistk. Levi-Strauss memandang bahwa antara mitos dan bahasa memiliki persamaan. Ia menyodorkan sebuah alat pembenaran untuk menggunakan metode analisis linguistik struktural yang dikaguminya dalam menganalisis mitos-mitos. Persamaan yang dimaksud adalah pertama, bahasa adalah sebuah media, alat, atau sarana untuk komunikasi, untuk menyampaikan pesan-pesan dari satu individu ke individu yang lain, dari kelompok yang satu ke kelompok yang lain. Kedua, mengikuti pandangan De Saussure tentang aspek bahasa langue dan parole. $^{5}$ 
Dikatakan oleh Leach $^{6}$ bahwa analisis struktural Levi-Strauss atas mitos sebenarnya juga dipengaruhi oleh teori informasi atau teori komunikasi.Bahwa mitos tidak hanya sekedar dongeng, tetapi mitos mengandung pesan yang ingin disampaikan kepada orang lain. ${ }^{7}$ Dengan demikian, dalam cerita rakyat tersimpan pesan yang ingin disampaikan oleh generasi terdahulu untuk menjadi pegangan atau pelajaran bagi generasi selanjutnya. Pesan tersebut dapat berupa pengalaman sejarah, pengetahuan, atau sebuah idealisme dan sebagainya. Oleh sebab itu, kajian terhadap cerita rakyat menjadi tepat sebagai salah satu upaya untuk mengungkap kearifan lokal masyarakat tertentu.

\section{Dalam Kamus Besar Bahasa} Indonesia ${ }^{8}$, kata kearifan diartikan sebagai kebijaksanaan dan kecendikiaan. Lebih luas dijelaskan oleh Ahimsa-Putrabahwa kata kearifanberasal dari kata arif yang merupakan serapan dari bahasa Arab yang artinya tahu dan mengetahui. Jadi kearifan dapat diartikan sebagai pengetahuan. Masih menurutnya, kata arif juga memiliki makna yang lebih luas karena kata arifjuga mencakup makna bijaksana, cerdikpandai, dan berilmu. Dari turunannnya terdapat kata kebijaksanaan yang antara lain diartikan sebagai kepandaian menggunakan akal budi, pimpinan, dan cara bertindak, kecakapan bertindak bila menghadapi orang lain, kesulitan, dan lain-lain. Singkatnya, kata kearifan didefinisikan dengan perangkat pengetahuan dan praktik-praktik untuk menyelesaikan persoalan dan/atau kesulitan yang dihadapi dengan cara yang baik, benar, dan bagus. ${ }^{9}$ Lihat juga Ahimsa-Putra. ${ }^{10}$

Kata lokal dalam Kamus Besar Bahasa Indonesia ${ }^{11}$ memiliki arti ruang yang luas;terjadi (berlaku, ada, dan sebagainya) di satu tempat, tidak merata; setempat. Secara ringkas, kearifan lokal berarti kearifan setempat. Pada akhirnya Ahimsa-Putra mendefinisikan kearifan lokal sebagai berikut :

"Perangkat pengetahuan dan praktik-praktik pada suatu komunitasbaik yang berasal dari generasigenerasi sebelumnya maupun dari pengalamannya berhubungan dengan lingkungan dan masyarakat lainnyauntuk menyelesaikan berbagai persoalan dan/atau kesulitan yang dihadapi secara baik, benar, dan bagus". ${ }^{12}$ Lihat juga Ahimsa-Putra. ${ }^{13}$

Sebagai tujuan akhir tulisan ini adalah untuk mengungkap kerifan lokal masyarakat Sasak yang terdapat dalam cerita Cilinaye. Yang menjadi pertanyaan selanjutnya adalah bagaimana cara mengungkap kearifan lokal yang dimaksud. Mungkin sudah banyak metode analisis atau metode mengungkap kearifan lokal dalam sebuah cerita pada penelitian-penelitian sebelumnya. Akan tetapi dalam tulisan ini yang akan digunakan adalah metode yang dikemukakan oleh Ahimsa-Putra. 
Metode ini dipilih karena dianggap mudah dan efektif digunakan untuk mengungkap kearifan lokal dalam sebuah cerita.

Dalam mengungkap, menurut Ahimsa-Putra $^{14}$ ditekankan harus dipahami dahulu unsur emik dan unsur etik. Yang dimaksud unsur emik dari sebuah teks atau karya adalah satuansatuan yang menurut individu atau masyarakat penghasil teks tersebut merupakan satuan-satuan yang membentuk teks tersebut, sedangkan unsur etik merupakan cara dan kriteria tersendiri peneliti dalam melakukan klasifikasi, yang kemudian akan menghasilkan kategori-kategori yang berbeda dengan yang dimiliki oleh masyarakat yang diteliti. Kategori tersebut oleh Levi-Strauss disebut mytheme (mitem). Kategori ini ditambahkan oleh Ahimsa-Putra dengan apa yang ia sebut sebagai ceritem. ${ }^{15}$ Mitem menurut LeviStrauss ${ }^{16}$ adalah unsur-unsur dalam konstruksi wacana mitis yang juga merupakan satuan-satuan yang bersifat kosokbali, relatif, dan negatif. Atau yang disederhanakan oleh AhimsaPutra dengan definisinya yakni kalimat-kalimat yang menunjukkan adanya relasi-relasi tertentu di antara tokoh-tokoh dalam sebuah karya sastra. Sedangkan ceritem menurut AhimsaPutra $^{17}$ adalah satuan-satuan dalam karya sastra, bisa berupa sejumlah kalimat, sebuah alinea, atau sejumlah alinea, yang memperlihatkan suatu gambaran atau pandangan tertentu. Dua hal inilah yang disusun untuk memudahkan dilakukan analisis. Dengan demikian ketika melakukan analisis, suatu cerita akan dipisah-pisah menjadi beberapa episode cerita.

Selanjutnya dalam upaya mengungkap kearifan lokal, AhimsaPutra $^{18}$ membagi kearifan yang terkandung dalam karya sastra berdasarkan keterwujudannya dalam teks menjadi tiga macam, yakni kearifan yang tersurat, tersirat, dan terpendam. Lebih lanjut dijelaskan bahwa kearifan yang tersirat mudah diketahui dari kata-kata, kalimat, atau alinea dalam teks karena dinyatakan secara eksplisit, secara terang-terangan. Kearifan yang tersirat dapat diketahui setelah membaca teks dengan lebih teliti dan dapat mengambil jarak dengan teks tersebut. Sedangkan kearifan yang terpendam merupakan kearifan yang lebih sulit lagi ditemukan karena tidak berada pada tataran kata, kalimat, tetapi pada tataran alinea atau unit lain yang setara, atau keseluruhan teks.

\section{Hasil dan Pembahasan}

\subsection{Analisis Struktural Cerita}

Dalam cerita ini ditemukan beberapa tokoh penting di antaranya Datu Keling dan Datu Dehe. Dua tokoh ini bersaudara dan sama-sama menjadi raja.Datu Keling memiliki putra bernama Raden Panji sedangkan Datu Dehe memiliki seorang putri bernama Cilinaye. Selain itu ada juga tokoh 
Amaq Bangkol dan Inaq Bangkol serta para pengawal Raden Panji.

Dalam menganalisis struktur cerita Cilinaye, sebagaimana telah disebutkan di atas, terlebih dahulu perlu ditentukan mitem dan ceritem dari cerita ini. Setelah membaca keseluruhan teks, penulis dapat menentukan beberapa ceritem. Ceritem berawal pada bagian pembuka dari cerita Cilinaye yang langsung berhadapan dengan permasalahan dua tokoh yang sama-sama belum memiliki anak. Permasalahan tersebut terdapat pada penggalan cerita berikut.

Ada dua orang raja bersaudara, Datu Keling dan Datu Dehe. Mereka berdua samasama belum memiliki anak. Kondisi ini membuat kawula bala Datu Keling dan Datu Dehe resah karena siapa yang akan menjadi pengganti kedua raja tersebut jika mereka tidak memiliki keturunan. Penasihat Datu Keling dan Datu Dehe memberikan saran bahwa satu-satunya yang dapat mewujudkan keinginan tersebut adalah dengan memohon di suatu tempat yang disebut Makam Keramat yang berada di Kayangan.

Dari penggalan di atas, dapat terlihat bahwa cerita dimulai dengan permasalahan yang dihadapi oleh tokoh Datu Keling dan Datu Dehe yakni mereka sulit mendapatkan ketururan. Kondisi ini tidak hanya mengkhawatirkan kedua tokoh tersebut, akan tetapi seluruh kawula bala juga ikut khawatir. Kedua tokoh tersebut akhirnya meminta saran kepada para penasihat dan ditemukanlah solusi. Satu-satunya jalan untuk menyelesaikan permasalah tersebut adalah dengan memohon di sebuah tempat yakni makam keramat yang berada di Kayangan.

Banyak yang dapat diungkap dari penggalan cerita ini. Pada penggalan cerita di atas dapat kita lihat adanya permasalahan dan adanya solusi. Dengan gambling, penggalan ini mengungkap bagaimana menyelesaikan masalah yang dialami selama bertahun-tahun dan sulit diselesaikan. Penyelesaian tersebut lahir dari seorang penasihat yang menyarankan agar memohon ke makam keramat yang berada di Kayangan. Ketika kedua tokoh tersebut sudah tidak mampu lagi mewujudkan keinginannya, yang menyebabkan lahirnya kekhawatiran di semua pihak, ternyata dikatakan oleh penasihat bahwa hanya dengan memohon ke makam keramatlah yang mampu menyelesaikan permasalahan tersebut.

Ada hal lain juga yang perlu dipahami dari penggalan cerita ini yakni disebutkannya makam keramat yang berada di Kayangan. Apa itu keramat dan apa itu kayangan. Dalam Kamus Besar Bahasa Indonesia kata keramat diartikan sebagai suci dan dapat mengadakan sesuatu di luar kemampuan manusia biasa karena ketakwaannya kepada Tuhan. Sedangkan kata keramat diartikan 
tempat dewa; surgaloka. Dari makna kedua kata tersebut dapat disimpulkan bahwa tempat memohon tersebut merupakan tempat suci yang berada di surga.

Walaupun dalam bagian cerita ini disebutkan bahwa Datu Dehe dan Datu Keling ketika pergi memohon ke tempat keramat itu mengajak kawula bala juga, akan tetapi disebutkannya tempat itu berada di surga menafikan bahwa tempat memohon itu berada di sebuah tempat di bumi ini berdasar pada perspektif kita. Berdasarkan hal itulah, penulis mengambil kesimpulan bahwa sebenarnya solusi yang diberikan pada penggalan cerita di atas adalah agar selalu memohon kepada yang mahasuci.

Pada bagian selanjutnya, Datu Keling dan Datu Dehe pergi ke tampat keramat itu dan di sana mereka menyampaikan permohonannya dengan disertai mengucapkan nazar.

Di tempat tersebut Datu Keling menyampaikan keinginan semoga dianugrahi anak laki-laki, sedangkan Datu Dehe menyampaikan keinginan semoga dianugrahi anak perempuan. Datu Dehe menyatakan sesangi-nya (nazar) bahwa jika keinginannya terkabul nanti ia akan membawa dua ekor kerbau bertanduk emas, berambut sutra, dan berkuku perak. Datu Keling juga menyatakan sesangi (nazar), tetapi tidak semuluk seperti yang disampaikan oleh Datu Dehe karena dia takut nantinya jika tidak mampu membayar. Nazar Datu Keling hanya selembar daun sirih, ditambah kapur, dan buah pinang.

Dalam penggalan cerita ini, Datu Dehe mengucapkan nazar yang Datu Keling dan Datu Dehe sama-sama sangat mengejutkan yakni akan menyampaikan permohonannya. Akan membawa dua ekor kerbau bertanduk tetapi Datu Keling menginginkan emas, berambut sutra, dan berkuku seorang anak laki-laki sedangkan Datu perak, sedangkan Datu Keling Dehe menginginkan anak perempuan. mengucapkan nazar yang sederhana Datu Keling dan Datu Dehe juga sama- yakni selembar daun sirih, ditambah sama mengucapkan nazar. Akan tetapi kapur, dan buah pinang.

nazar yang mereka ucapkan berbeda.

Setelah sembilan bulan terwujudlah impian Datu Dehe dan Datu Keling untuk memiliki anak sesuai harapannya, Datu Dehe anak perempuan yang kemudian diberi nama Putri atau Dewi Ratna Sari dan Datu Keling anak laki-laki yang kemudian diberi nama Raden Panji. Setelah terwujud harapannya, Datu Keling langsung membayar nazar dengan seekor kerbau walaupun nazar sebenarnya adalah selembar daun sirih, kapur, dan buah pinang. Sedangkan Datu Dehe belum mampu membayar nazarnya.

Pada penggalan cerita ini, yang menjadi titik perhatian kita adalah terlihatnya sikap kosokbali dari dua tokoh Datu Keling dan Datu Dehe.
Sikap ini juga berlawanan dengan sikap kedua tokoh tersebut pada bagian cerita sebelumnya. Datu Dehe yang sebelumnya mengucapkan nazar begitu 
mengejutkan, di samping jumlahnya yang sangat banyak, nazar dari Datu Dehe juga terbilang aneh atau merupakan sesuatu yang sulit ditemukan. Selain itu, Datu Dehe juga tidak membayar nazar ketika permohonannya sudah didapatkan. Sebaliknya, Datu Keling yang mengucapkan nazar sederhana berupa selembar daun sirih, ditambah kapur, dan buah pinang, malah membayarnya dengan yang lebih besar lagi, yakni membayar dengan seekor kerbau.

Sampai di sini, yang perlu menjadi catatan adalah adanya oposisional antara dua tokoh tersebut. Tokoh yang satu menjanjikan sesuatu yang besar, walaupun pada akhirnya semua itu tidak mampu dibayar. Tokoh yang satu lagi menjanjikan sesuatu yang sederhana tetapi membayarnya dengan sesuatu yang lebih besar. Dapat kita tafsirkan bahwa tokoh yang satu menunjukkan sikap tidak bersyukur terhadap apa yang didapatkan, sedangkan tokoh yang satu lagi menunjukkan sikap bersyukur terhadap apa yang didapatkan.

Bagi penulis, penggalan cerita ini belum memberikan atau menyampaikan suatu makna yang berarti karena pada bagian ini kita baru mendapatkan dua sikap yang berbeda tanpa mendapatkan implikasi dari masing-masing sikap. Akan tetapi bukan berarti bagian ini menjadi tidak penting dibandingkan dengan bagian cerita yang lainnya. Di sinilah terlihat bahwa setiap bagian cerita merupakan bagian dari makna menyeluruh suatu cerita. Bagian ini belum dapat memberikan makna jika tidak dihubungkan dengan bagian yang lain. Bagian in akan mendapatkan penjelasan oleh bagian yang lain.

Selanjutnya, kenapa memotong kerbau menjadi nazar dari Datu Dehe, begitu juga dengan Datu Keling yang menunjukkan rasa syukurnya dengan memotong kerbau. Kerbau merupakan simbol dari sesuatu yang berharga. Di sampingitu, kerbau juga menjadi kebanggaan. Mengorbankan sesuatu yang berharga untuk diberikan kepada orang lain merupakan suatu kearifan yang dicontohkan dalam cerita ini. Pada bagian selanjutnya terlihatlah implikasi dari sikap yang ditunjukkan pada bagian sebelumnya.

Pada suatu hari di lingkungan istana Datu Dehe, Putri diajak bermain di taman. Ketika Putri bermain di taman datanglah angin puting beliung yang langsung menyambar Putri dan membawanya terbang. Putri jatuh ke tangan pangkuan Inaq Bangkol dan Amak Bangkol yang kemudian merawatnya sampai dewasa. Oleh Inak Bangkol dan Amaq bangkol, Putri diberi nama Cilinaye. Namun hal ini tidak diketahui oleh Datu Dehe. Menghadapi kenyataan seperti itu, Datu Dehe hanya bisa pasrah dan hal itu membuatnya sadar mungkin selama ini ia telah salah berbuat. 
Pada bagian ini, ada dua hal yang menjadi titik perhatian. Kedua titik tersebut adalah diterbangkannya Cilinaye yang kemudian jatuh ke tangan Amaq Bangkol dan Inaq Bangkol serta yang kedua adalah kesadaran yang timbul dari Datu Dehe. Setelah Cilinaye diterbangkan oleh angin, Datu Dehe sadar akan kesalahan yang telah diperbuat yakni tidak membayarkan nazar yang diucapkan ketika menyampaikan permohonannya.

Kejadian yang terjadi pada bagian ini menjadi jawaban atas sikap yang ditampilkan pada bagian cerita sebelumnya. Sikap yang dimaksud adalah sikap antara Datu Dehe dengan
Datu Keling yang berbeda dalam hal membayar nazar yang telah diucapkan, bahkan tidak hanya berbeda, bagian tersebut menampilkan sebuah ironi. Datu Keling yang hanya bernazar dengan hal yang sederhana, malah membayarnya dengan yang lebih besar. Begitu sebaliknya dengan Datu Dehe. Inilah yang penulis maksudkan dengan penjelasan terhadap bagian sebelumnya. Kejadian diterbangkannya Cilinaye menjelaskan bahwa sikap yang diperlihatkan oleh Datu Dehe adalah sikap yang salah. Hal ini juga diperkuat dengan pengakuannya yang mengatakan bahwa dirinya mungkin telah melakukan kesalahan.

Pada waktu berburu Raden Panji bertemu dengan Cilinaye dan kemudian menikahinya. Sejak awal, ayah Raden Panji tidak setuju dengan pernikahan putranya bersama Cilinaye karena perbedaan derajat antara putranya dengan Cilinaye yang berasal dari keluarga rendahan yakni keluarga Inaq Bangkol dan Amaq Bangkol. Puncak dari ketidaksetujuan itu adalah timbulnya niat dari ayah Raden Panji untuk membunuh Cilinaye. Raden Panji diminta pergi mencari hati rusa putih. Raden Panji terpaksa harus berpisah dengan Cilinaye. Selepas keberangkatan Raden Panji berburu mencari hati rusa putih, saat itulah Cilinaye dan anaknya dibawa ke tanjung menangis untuk dibunuh.

Pada bagian ini, timbul akan membunuh Cilinaye. permasalahan pada pihak Datu Keling Permasalahan yang ada langsung yakni Raden Panji menikahi Cilinaye, diselesaikan dengan suatu keputusan anak dari Amaq Bangkol dan Inaq Bangkol. Hal inilah yang membuat Datu Keling, ayah Raden Panji, menjadi malu. Datu Keling tidak setuju melihat anaknya menikahi Cilinaye yang dia tahu berasal dari keluarga rendahan. Datu Keling bersiasat meminta Raden Panji mencari hati rusa putih. Ketika Raden Panji pergi berburu mencari hati rusa putih, pada saat itulah Datu Keling bermaksud akan membunuh Cilinaye. Tentu Datu Keling tidak ingin jika anaknya mengetahui niat untuk membunuh Cilinaye tersebut. Itulah sebabnya Datu Keling meminta Raden Panji pergi mencarikannya hati rusa putih.

Permasalahan yang ada pada bagian cerita di atas langsung mendapatkan solusi untuk menyelesaikannya. Yang menjadi pertanyaan kemudian adalah apakah 
solusi tersebut merupakan sebuah merupakan sesuatu yang tidak kearifan yang diberikan pada bagian cerita ini. Jika kita mengacu kepada definisi kearifan lokal yang telah dipaparkan pada bagian awal tulisan ini, tentu jawabannya adalah tidak. Akan tetapi kenyataan yang kita lihat pada bagian cerita ini seperti itu, ada yang dikorbankan atau ada yang disakiti. Bukanlah kearifan lokal namanya jika solusi tersebut dilakukan dengan baik, benar, dan bagus. Di sinilah terlihat bahwa bagian cerita merupakan bagian dari sebuah struktur yang tidak dapat berdiri sendiri. Bagian tersebut akan menemukan makna sebenarnya atau penjelasannya ketika dikaitkan dengan bagian-bagian lainnya secara menyeluruh. Mari kita lihat bagian selanjutnya dari cerita ini.

Sesampainya di Tanjung Menangis, Cilinaye langsung dibunuh, tetapi tidak sedikit pun badannya terluka. Melihat algojo itu bingung, Cilinaye pun memberitahukan pepatih bahwa dia hanya bisa ditusuk dengan rumput ilalang sebanyak sembilan buah. Sebelum ditusuk Cilinaye mengatakan bahwa seandainya darahnya nanti tidak memancar ke langit dan berbau harum maka dia bukanlah seorang putri. Akhirnya terbukti ketika badannya ditusuk, memancarlah darah Cilinaye ke atas langit dan berbau harum sekali sehingga pepatih percaya bahwa isteri Raden Panji memang seorang putri. Pada perjalanan pulang entah dari mana datangnya hujan angin, kilat, dan petir yang menyambar mereka hingga hanya satu orang saja yang bisa sampai kepada Datu Keling untuk menceritakan bahwa isteri Raden Panji memang seorang Putri. Kejadian ini membuat Datu Keling heran dan menyesal memerintahkan untuk membunuh Cilinaye.

Bagian cerita ini seolah-olah angin, kilat, dan petir yang menyambar menjelaskan atau memberi jawaban bahwa penyelesaian masalah yang para algojo dan patih sehingga menyisakan satu orang saja adalah satu dilakukan oleh Datu Keling pada bukti bahwa apa yang mereka lakukan bagian cerita sebelumnya merupakan penyelasaiaan yang salah. Hal tersebut itu adalah perbuatan yang buruk, tidak layak untuk dilakukan. Selain itu, sikap ditunjukkan dengan suatu kejadian penyesalan yang ditunjukkan oleh Datu dalam struktur cerita ini yang Keling merupakan suatu penjelasan menjelaskan bahwa Cilinaye sebenarnya seorang putri, bukan dari keluarga rendahan. Datangnya hujan bahwa bentuk penyelesaian masalah yang ia lakukan adalah penyelesaian yang salah.

Setelah beberapa lama, Cilinaye yang hanyut bersama petinya ditemukan dalam keadaan hidup oleh Datu Dehe yang sedang mandi di Tanjung Menangis. Sebagai wujud syukur atas kembalinya Cilinaye yang telah lama hilang diterbangkan angin, Datu Dehe mengadakan pesta dengan menabuh alat musik dan peresean. Acara pesta dengan suara alat musik dan peresean ini terdengar juga ke telinga Raden Panji dan anaknya. Akhirnya di acara pesta itu bertemulah Cilinaye dengan anak dan suaminya. 
Bagian akhir cerita ditutup akhirnya bertemu kembali dengan dengan bertemunya Datu Dehe dengan suami dan anaknya. Dengan anaknya Cilinaye yang dulu berkumpulnya kembali Cilinaye diterbangkan oleh angin. Pertemuan tersebut kemudian dirayakan oleh Datu Dehe dengan mengadakan pesta. Pada pesta tersebut diramaikan oleh penabuhan alat musik dan mengadakan peresean. Seluruh kawula bala ikut berpesta sebagai bentuk rasa syukur mereka atas kembalinya Cilinaye, putri dari Datu Dehe. Pada pesta ini, Cilinaye akhirnya bertemu kembali dengan anak dan suami yang telah lama berpisah dengannya.

Sebagai bagian akhir dari sebuah cerita, bagian ini menutup rentetan struktur cerita Cilinaye. Pada bagian ini kita dapat melihat bagaimana struktur bagian ini menutup atau memperlihatkan suatu sikap yang idealnya dilakukan. Tidak hanya bagi Datu Dehe sebagai raja, akan tetapi menjadi idealisme bagi seluruh kawula bala atau rakyat juga. Terlihat pada bagian akhir ini, ketika Datu Dehe telah menyesali akan kesalahan yang pernah dia perbuat, Cilinaye yang selama ini hilang diterbangkan oleh angin akhirnya kembali kepadanya. Selanjutanya ketika keadaan ini disyukuri oleh Datu Dehe dan seluruh kawula bala atau rakyat, Cilinaye bersama Datu Dehe, anak, dan suaminya, keadaan kembali pada kondisi semula. Permasalahan yang ada pada bagian awal telah teratasi. Tidak ada lagi kekhawatiran pada kedua raja tersebut, karena sudah ada yang akan meneruskan kekuasaan mereka.

Ada dua hal dalam cerita ini yang digolongkan sebagai sesuatu yang tidak benar atau tidak layak dilakukan. Ketidaklayakan tersebut tidak dikatakan secara langsung akan tetapi dijelaskan secara tersirat dengan kejadian lain sebagai akibat dari perbuatan tersebut. Dua bagian cerita tersebut adalah diterbangkannya Cilinaye akibat dari Datu Dehe yang tidak menunaikan nazar dan kejadian aneh ketika Cilinaye akan dibunuh yang akhirnya diketahui bahwa Cilinaye ternyata merupakan seorang putri. Cara ini, yakni dengan menjelaskan sesuatu yang tidak pantas dengan cara yang baik dalam cerita ini merupakan salah satu yang dapat dikatakan sebagai kearifan lokal.

Jika diringkas dalam bentuk skema, struktur cerita Cilinaye di atas dapat digambarkan seperti di bawah ini 
Skema Struktur Cerita Cilinaye.

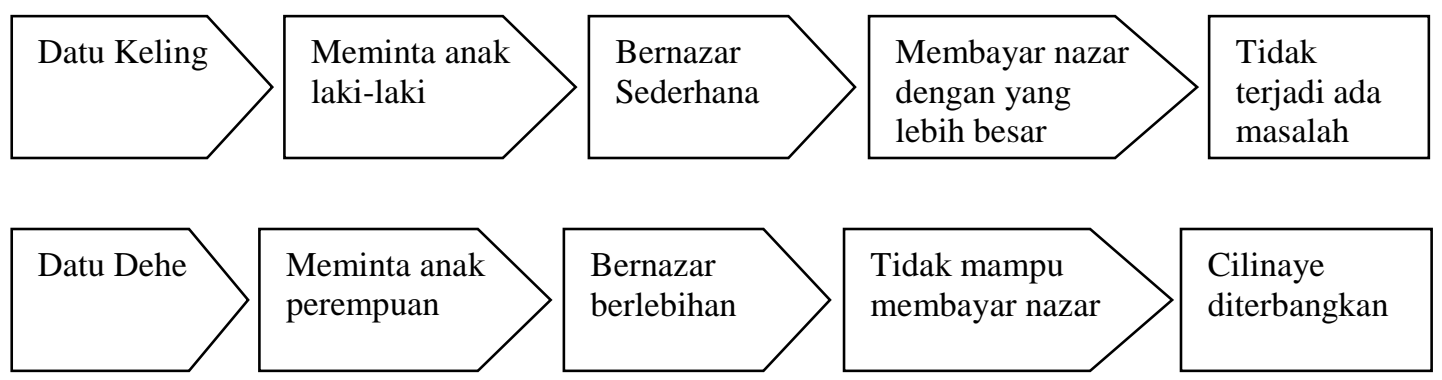

Skema 2.

\begin{tabular}{|l}
$\begin{array}{l}\text { Raden Panji } \\
\text { menikahi } \\
\text { Cilinave }\end{array}$
\end{tabular}$>\begin{aligned} & \begin{array}{l}\text { Datu Keling tidak } \\
\text { setuju. memandang } \\
\text { rendah Cilinaye }\end{array}\end{aligned}>\begin{aligned} & \begin{array}{l}\text { Membunuh } \\
\text { Cilinaye }\end{array}\end{aligned}>\begin{aligned} & \begin{array}{l}\text { Cilinaye terbukti } \\
\text { sebagai seorang } \\
\text { putri }\end{array}\end{aligned}>$\begin{tabular}{l}
$\begin{array}{l}\text { Datu } \\
\text { Keling } \\
\text { menyesal }\end{array}$ \\
\hline
\end{tabular}

Skema 3.

\begin{tabular}{|c|c|c|c|c|}
\hline $\begin{array}{l}\text { Datu Dehe } \\
\text { menyadari } \\
\text { kesalahan }\end{array}$ & $\begin{array}{l}\text { Bertemu } \\
\text { dengan } \\
\text { Cilinaye }\end{array}$ & $\begin{array}{l}\text { Bersyukur } \\
\text { Dengan kembalinya } \\
\text { Cilinaye }\end{array}$ & $\begin{array}{l}\text { Cilinaye Bertemu } \\
\text { dengan anak dan } \\
\text { suami }\end{array}$ & $\begin{array}{l}\text { Hidup } \\
\text { Bahagia }\end{array}$ \\
\hline
\end{tabular}

\subsection{Kearifan Lokal}

Dari analisis struktur di atas, dapat terlihat beberapa kearifan lokal yang terkandung di dalam cerita Cilinaye ini. Pada bagian awal, cerita ini langsung mengedepankan sebuah masalah yakni sulitnya Datu Dehe dan Datu Keling memiliki anak. solusi dari masalah tersebut adalah agar memohon ke makam keramat yang ada di kayangan. Ini merupakan salah satu kearifan lokal yang dimiliki oleh masyarakat sasak. Berdoa ke makam dalam mewujudkan keinginan adalah sebuah tradisi yang sering dilakukan oleh banyak masyarakat Sasak. Hal ini bukan berarti memanjatkan doa kepada orang yang sudah mati, tetapi ketika berziarah ke makamdipanjatkanlah doa atau harapan kepada yang mahasuci sebagaimana telah dijelaskan pada analisis bagian awal cerita.

Selain itu, pada bagian awal disebutkanlah nazar yang diucapkan oleh Datu Keling dan Datu Dehe. Dalam hal ini, nazar merupakan bagian dari penyelesaian masalah di atas. Berdoa dan bernazar merupakan dua hal yang saling mengait.Nazar yang dipahamai sebagai janji (pada diri sendiri) hendak berbuat sesuatu jika maksud tercapai (KBBI), tidak hanya sebuah janji. Secara tidak langsung, pada nazar terdapat sebuah kekuatan atau motivasi untuk terus berusaha dalam mencapai apa yang diinginkan. Dengan demikian hal ini pantas dikatakan sebagai kearifan lokal.

Rasa syukur atas kembalinya lagi putri satu-satunya yang telah lama menghilang karena diterbangkan oleh 
angin diwujudkan oleh Datu Dehe dengan mengadakan perayaan besarbesaran. Hal itu didapat setelah ia menyadari akan kesalahan yang pernah ia buat. Di tengah-tengah perayaan ini juga, Cilinaye bertemua kembali dengan suami dan anaknya. Dalam perayaan ini Datu Dehe melibatkan seluruh kawula bala untuk sama-sama merasakan kegembiiraan atas kembalinya lagi putri Cilinaye. Datu Dehe menyiapkan makanan dan memotong kerbau untuk memberi makan seluruh rakyat yang datang. Kerbau merupakan simbol suatu kebanggaan atau sesuatu yang berharga. Dengan demikian, memotong kerbau untuk diberikan kepada yang lain sebagai simbol dari tingginya rasa syukur. Dalam perayaan ini diadakan juga peresean disertai dengan tabuhan gendang-gendang.Semua itu merupakan kearifan lokal masyarakat Sasak sebagai wujud syukur atas apa yang telah dianugrahi oleh Tuhan.

Yang terakhir, struktur cerita ini sendiri merupakan suatu kearifan yang dimiliki oleh masyarakat Sasak. Struktur cerita Cilinaye ini menjelaskan dengan apik kepada pembaca tentang bagaimana kepantasan sebuah sikap dan perbuatan. Semua itu dijelaskan dengan suatu makna yang dapat terlihat pada bagian-bagian lain dari cerita tersebut. Sikap yang salah atau tidak pantas akan mengakibatkan keburukan dan sebaliknya sikap yang baik atau pantas akan mendatangkan kebahagiaan.

\section{Simpulan dan Saran}

\subsection{Simpulan}

Dari pembahasan di atas, setelah menganalisis cerita Cilinaye dengan pendekatan strukturalisme Levi-Strauss, penulis dapat menyimpulkan bagaimana struktur cerita Cilinaye. Hal ini terwujud setelah cerita dibagi menjadi beberapa bagian. Kemudian dari masing-masing bagian, penulis mencari sebuah makna yang terkait dengan makna bagian-bagian yang lain. Dengan demikian, cerita Cilinaye memiliki struktur yang saling kait-mengait antarbagian. Bagian yang satu dijelaskan dengan bagian yang lain. Adanya suatu sikap pada suatu bagian akan dijelaskan dengan sikap atau sebuah kejadian pada bagian yang lain. Dengan menggunakan pendekatan strukturalisme Levi-Strauss ini, penulis dapat mengungkap kearifan lokal masyarakat Sasak yang terdapat dalam cerita Cilinaye.

\subsection{Saran}

Sudah barang tentu, penelitian ini bukanlah sebuah penelititan yang sempurna. Oleh sebab itu, disarankan adanya penelititan yang lebih mendalam terhadap cerita Cilinaye dengan objek langsung kepada teks asli atau naskah lontarCilinaye khususnya dan terhadap teks atau naskah cerita Sasak lainnya guna mendapatkan hasil yang jauh lebih mendalam. Diharapkan dengan penelitian yang mendalam tersebut dapat diungkap lebih banyak lagi kearifan lokal yang tersimpan di 
dalam sastra daerah. Di samping dapat mengungkap dan menumbuhkan rasa kebanggaan dengan apa yang kita miliki, hasil tersebut dapat juga dimanfaatkan oleh bidang-bidang lain dalam pembangunan, salah satunya bidang pariwisata.

\section{DAFTAR PUSTAKA}

${ }^{1}$ Ahimsa-Putra, Heddy Shri. Kearifan Lokal dalam Sastra Metode untuk Menemukannya. Dalam Aprinus Salam dkk. (ed). Jejak Sastra dan Budaya. Prosiding Seminar Internasional untuk 70 Tahun Prof. Dr. Siti Chamamah Soeratno. Yogyakarta : FIB UGM dan Elmatera.

${ }^{2}$ http://jurnal.dikti.go.id/jurnal/kontributor (diakses pada tanggal 8 November 2011)

${ }^{3}$ Safarudin, Balok, dkk. 2010. Laporan penelitian "Orientasi Nilai Budaya Etnis Sasak yang Tercermin dalam Cerita Rakyatnya”. Mataram: Kantor Bahasa Provinsi NTB.

${ }^{4}$ Suwondo, Tirto. 2001.Analisis Struktural Salah Satu Model Pendekatan dalam Penelitian Sastra. dalam Jabrohim (Ed). Metodologi Penelitian Sastra. Yogyakarta: Hanindita dan Masyarakat Poetika Indonesia

${ }^{5}$ Ahimsa-Putra, Heddy Shri. 2006. Strukturalisme Levi-Strauss Mitos dan Karya Sastra. Yogyakarta : Kepel Press.

${ }^{6}$ Ahimsa-Putra, Heddy Shri. 2006. Strukturalisme Levi-Strauss Mitos dan Karya Sastra. Yogyakarta: Kepel Press.

${ }^{7}$ Ahimsa-Putra, Heddy Shri. 2006. Strukturalisme Levi-Strauss Mitos dan Karya Sastra. Yogyakarta: Kepel Press.

${ }^{8} \mathrm{KBBI}$ (Kamus Besar Bahasa Indonesia) versi offline dengan mengacu pada data dari KBBI Daring (edisi III) diambil dari http://pusatbahasa.diknas.go.id/kbbi/sekarang berganti http://pusatbahasa.kemdiknas.go.id/kbbi// Freeware (02010-1011 by Ebta Setiawan.

${ }^{9}$ Ahimsa-Putra, Heddy Shri. Kearifan Lokal dalam Sastra Metode untuk Menemukannya. Dalam Aprinus Salam dkk. (ed). Jejak Sastra dan Budaya. Prosiding Seminar Internasional untuk 70 Tahun Prof. Dr. Siti Chamamah Soeratno. Yogyakarta: FIB UGM dan Elmatera.

${ }^{10}$ Ahimsa-Putra. 2009. Bahasa, Sastra dan Kearifan Lokal di Indonesia. Dalam Mabasan Vol. 3 No. 1. Januari-Juni 2009. Kantor Bahasa Provinsi NTB. 
${ }^{11}$ KBBI (Kamus Besar Bahasa Indonesia) versi offline dengan mengacu pada data dari KBBI Daring (edisi III) diambil dari http://pusatbahasa.diknas.go.id/kbbi/sekarang berganti http://pusatbahasa.kemdiknas.go.id/kbbi// Freeware C2010-1011 by Ebta Setiawan.

${ }^{12}$ Ahimsa-Putra, Heddy Shri. Kearifan Lokal dalam Sastra Metode untuk Menemukannya. Dalam Aprinus Salam dkk. (ed). Jejak Sastra dan Budaya. Prosiding Seminar Internasional untuk 70 Tahun Prof. Dr. Siti Chamamah Soeratno. Yogyakarta: FIB UGM dan Elmatera.

${ }^{13}$ Ahimsa-Putra. 2009. Bahasa, Sastra dan Kearifan Lokal di Indonesia. Dalam Mabasan Vol. 3 No. 1. Januari-Juni 2009. Kantor Bahasa Provinsi NTB.

14 Ahimsa-Putra, Heddy Shri. Kearifan Lokal dalam Sastra Metode untuk Menemukannya. Dalam Aprinus Salam dkk. (ed). Jejak Sastra dan Budaya. Prosiding Seminar Internasional untuk 70 Tahun Prof. Dr. Siti Chamamah Soeratno. Yogyakarta: FIB UGM dan Elmatera.

${ }^{15}$ Ahimsa-Putra, Heddy Shri. Kearifan Lokal dalam Sastra Metode untuk Menemukannya. Dalam Aprinus Salam dkk. (ed). Jejak Sastra dan Budaya. Prosiding Seminar Internasional untuk 70 Tahun Prof. Dr. Siti Chamamah Soeratno. Yogyakarta: FIB UGM dan Elmatera.

${ }^{16}$ Ahimsa-Putra, Heddy Shri. 2006. Strukturalisme Levi-Strauss Mitos dan Karya Sastra. Yogyakarta: Kepel Press.

${ }^{17}$ Ahimsa-Putra, Heddy Shri. 2006. Strukturalisme Levi-Strauss Mitos dan Karya Sastra. Yogyakarta: Kepel Press.

${ }^{18}$ Ahimsa-Putra, Heddy Shri. 2006. Strukturalisme Levi-Strauss Mitos dan Karya Sastra. Yogyakarta: Kepel Press. 
84| Mabasan, Vol. 6 No. 2, Juni-Desember 2012 